\title{
Children, waste and well-being: A critical analysis of socio-environmental justice in almajirai solid waste management in Northern Nigerian Cities
}

\author{
Ambrose O. Iheanacho', Peter O. Mbah ${ }^{2}$, Precious C. Onwuaha ${ }^{3}$, \\ Eberechukwu J. Eze ${ }^{3}$ \& Thaddeus C. Nzeadibe ${ }^{3}$
}

${ }^{1}$ Social Science Unit, School of General Studies, University of Nigeria,

\author{
Nsukka, Nigeria \\ ${ }^{2}$ Department of Political Science, University of Nigeria, Nsukka, \\ Nigeria \\ ${ }^{3}$ Department of Geography, University of Nigeria, \\ Nsukka, Nigeria \\ Email:chidi.nzeadibe@unn.edu.ng
}

\begin{abstract}
Context: Whereas academic discourse on socio-environmental justice (SEJ) globally has focused on race, ethnicity and wealth, and gender inequalities, research on SEJ in relation to children, their wellbeing and waste management in Africa has remained neglected.This paper focuses on the Almajirai, children in the Islamic educational system, and critically examines SEJ in Almajirai involvement in the solid waste management (SWM) system of cities in northern Nigeria.

Data Source and Method: The study is situated in the city of Zaria, Kaduna State, Nigeria. Mixed methods approach used for data collection included consultations with key stakeholders, ethnographic and field observations; key informant interviews (KIls), questionnaire survey of 350 respondents sampled purposively, and a critical review of literature. Percentages were utilized for analysis of quantitative data while quotations and transcriptions were made from interviews.

Findings: Findings indicate that while many Almajirai contribute to environmental well-being through collection, disposal and recycling of waste, they often suffer unbridled socio-environmental injustice in their quest for a livelihood and also for their perceived association with insecurity in northern Nigeria.

Conclusion: In the light of the findings and the overarching juvenile-related sustainable development goals (SDGs) targets, the paper rethinks the role of Almajirai in SWM while articulating possible policy benefits of scaling up engagement with Almajirai in the post-20I5 development era.
\end{abstract}

Keywords: Almajirai; solid waste management; sustainable development goals; well-being; socioenvironmental justice

\section{Introduction}

The problem of solid waste management (SWM) is highly visible in many African cities. The ubiquitous waste materials in these urban centres represent a major threat to public health and environmental wellbeing (Haregu et al 20I6). Paradoxically, urban waste is also an important source of livelihood to a significant number of people in the informal waste economy. The perpetual garbage glut in cities of Africa, however, has profound implications for social and environmental justice (SEJ) for populations in the informal economy who are inequitably imposed with the health and social burdens of the failure of society in SWM, i.e. 'the differential environmental health threats' (Parizeau 2006: 104) to which informal waste workers are perennially exposed in the course of extracting value from garbage.
Ironically, recent evidence points to the increasing relevance of the informal economy in the management of urban solid waste in African cities (Adama and Nzeadibe 2017). In Nigeria, however, the ever increasing interest in the role of the informal economy in SWM has focused attention mostly on cities of southern Nigeria where a thriving and dynamic informal waste economy is well documented (Adeyemi et al. 2001; Agunwamba 2003; Nzeadibe and Iwuoha, 2008; Nzeadibe, 2009; Nzeadibe and Ajaero, 20II, Nzeadibe et al, 2012). Surprisingly, only a smattering of research has emerged on northern Nigerian cities (Adama, 20I4; 20I2a; Ukoje 20I2), despite the existence of predisposing socio economic and cultural conditions such as pervasive poverty, a progressively declining economy, widespread culture of recovery of materials from 
waste, and the recognition of socioeconomic benefits inherent in the informal waste economy (Coles 1991; Nzeadibe and Adama 2015). More importantly, the glaring academic neglect of SEJ in informal solid waste management (ISWM) - a livelihood with linkages to a number of the Sustainable Development Goals targets (UNEP \& ISWA 20I5) and prevalent in many developing country cities, but which was unfortunately not captured in the post-2015 international development agenda (Mbah and Nzeadibe 2017) - speaks volumes about global commitment to attaining the SDGs. While the SDGs purport to 'leave no one behind', and that 'SDGs are against environmental discrimination and for environmental justice', (Citizen's Platform for SDGs, Bangladesh 2017), observations regarding the informal waste economy of northern Nigeria would seem to suggest the contrary.

Social justice addresses issues of inequity through social redistribution of the benefits of society (Scott and Oelofse 2005: 448) while environmental justice is about social transformation directed towards meeting basic human needs and enhancing the quality of lifeeconomic quality, health care, housing, human rights, environmental protection and democracy (Environmental Justice Network Forum 1997). While the discourse on environmental justice globally has been more concerned with race, ethnicity and wealth and gender inequalities (Buckingham et al, 2005), research on environmental justice in relation to children and waste management in Africa has remained a neglected theme. The Child Rights Act (2003) defines a child as a person below the age of 18 years (UNICEF Nigeria Fact Sheet 20II). This research focuses on SEJ of the Almajirai, that is, children in the Islamic educational system of northern Nigeria. It is estimated that more than 9.5 million Almajirai exist in Nigeria with Kaduna state accounting for 824,233 (Abdullahi 2017: 155). A significant number of these children are involved in unregulated collection, disposal and recycling of waste as a livelihood (Rigasa et al 2015; Abdullahi 2017, Ahmed et al 2017). This study further notes that involvement of children of school age in waste picking in northern Nigeria is related to the cultural mores of the region and is itself a pervasive social problem that mirrors the extent of exclusion and low level of human capital and social development of children in northern Nigerian society (Aluaigba 2009).

Because of their age, children are particularly vulnerable to the health and social consequences of environmental degradation and injustice (Landrigan et al. 2010). In the case of the Almajirai, the physical and social environments are both abysmal and hostile. For example, due to their frequent exposure to dirt and 4167 vermin in the process of waste collection, disposal and recycling, and their frequent contact with the urban population, Almajirai are a potential source of public and community health concerns (Nguyen et al 2003; Wilson et al. 2006). They are also known to perch precariously in dangerous housing conditions such as in shanties and dumpsites (Mbah and Nzeadibe 2017). Such situation is further exarcerbated by the daily victimization of Almajirai in urban governance process and policies as they are often seen as thieves and miscreants in urban areas. Moreover, child waste picking in northern Nigeria represents one of the worst forms of child labour (WFCL) (Nzeadibe and Mbah 2015; International Labour Organization 2004). All these combined call for a fundamental rethinking of the neglect of SEJ in the Almajirai SWM system in the light of the juvenile related SDGs.

While earlier studies have examined children's access and spatial exclusion in the recovery of recyclable materials from urban space (Adama 2012, Adama 20l4; Ukoje 20l7; Ahmed et al, 20l7), implications of Almajirai participation in ISWM on children's health and social well-being have barely been considered (Hunt 1996) thus, justifying the critical concerns of SEJ in the Almajirai SWM system. The point of departure of this paper, therefore, rests on the fact that while previous studies have alluded to vulnerability of the livelihood of ISWM in Nigerian cities (Nzeadibe et al. 2012; Nzeadibe and Mbah 20I5), and the place and integration of Almajirai SWM in the urban political economy of northern Nigeria (Adama 2012; Adama 2014; Abdullahi 2017), very little research exists on SEJ and children within Almajirai SWM.

In the light of the provisions of the Child Rights Act (2003), the present study adopts a case study approach to ground the empirical investigation in SEJ on a vulnerable and marginalized segment of the urban waste economy in northern Nigeria, especially as Almajirai are unfortuntely being perceived as tools in the recent upsurge in national security concerns. This paper utilizes the framework of the sustainable development goals (SDGs), to rethink SEJ and also reconsiders the role of Almajirai in SWM while highlighting possible benefits in the light of growing socioeconomic, environmental and security concerns in Nigeria.

\section{Data and methods}

This case study was situated in the city of Zaria, where the Ahmadu Bello University, the largest university in northern Nigeria is domiciled. Zaria is a major city in Kaduna State in Northern Nigeria and is second in size and importance only to the state 
capital, Kaduna (Figure I). This urban area is broadly representative of conditions in the Almajirai system of northern Nigeria and presents an appropriate arena for critical engagement and informed analysis on urban processess and governance among researchers, planners and other stakeholders. Qualdominant mixed methods used for data collection in this research included consultations with key stakeholders, ethnographic and field observations; key informant interviews (KIls), questionnaire survey as well as the use of secondary data.

Ethnographic techniques were adopted to enable a close observation and description of the living and working conditions of the Almajirai as was done in previous studies on the informal waste economy in Nigeria (Adama 20I2a, Nzeadibe et al. 20I2). Due to cultural and religious sensitivities, consultations with key stakeholders were conducted in order to obtain their prior informed consent to undertake the fieldwork. It also helped to elicit the cooperation and commitment of the communities in Zaria as partners and not merely as observers in the study. Some of the key stakeholders consulted were the Sarki Samaru, a Mallam in an Islamic school, as well as the Chief Security Officer of Samaru Constituency. KIls were conducted with the traditional ruler, two university professors, two officials of the Kaduna State Environmental Protection Authority (KEPA), and three urban researchers who are indigenes of the study area and who were opinion leaders and possessed in-depth knowledge of the environmental challenges, culture and social systems of the area. A focus group discussion (FGD) of fifteen persons was also carried out in Zaria comprising final-year university undergraduate students, residents and individuals who had previously conducted research on aspects of the Almajirai system, as well as the Almajirai themselves. This activity was carried out in the Hausa language relying on the fluency of one of the researchers in the language. It was done to gauge perceptions of people on the activities and the role the Almajirai play in SWM in Zaria. Field observations were made at Almajiri schools at Danraka and at Hayin Dogo (where the population of the pupils is approximately 160 and 228 respectively) to directly observe their living conditions. Households outside the Ahmadu Bello University where the Almajirai go to collect waste and dumpsites in Samaru were also observed for the frequency of waste collection, means of transportation of the collected waste, financial transactions that occur between the households and the Almajirai, their lifestyle and living conditions, occupational health issues and social challenges facing them in the course of waste collection, recycling and disposal.

Survey data were obtained by the researchers to complement the qualitative data. Both structured and semi-structured questions were asked in the questionnaire and in cases where community respondents were not able to read and write, administration of the questionnaire was done orally. This was carried out to obtain the views, insights and perceptions of people especially the semi-literate and illiterate members of the communities in Zaria. The respondents were sampled purposively. 


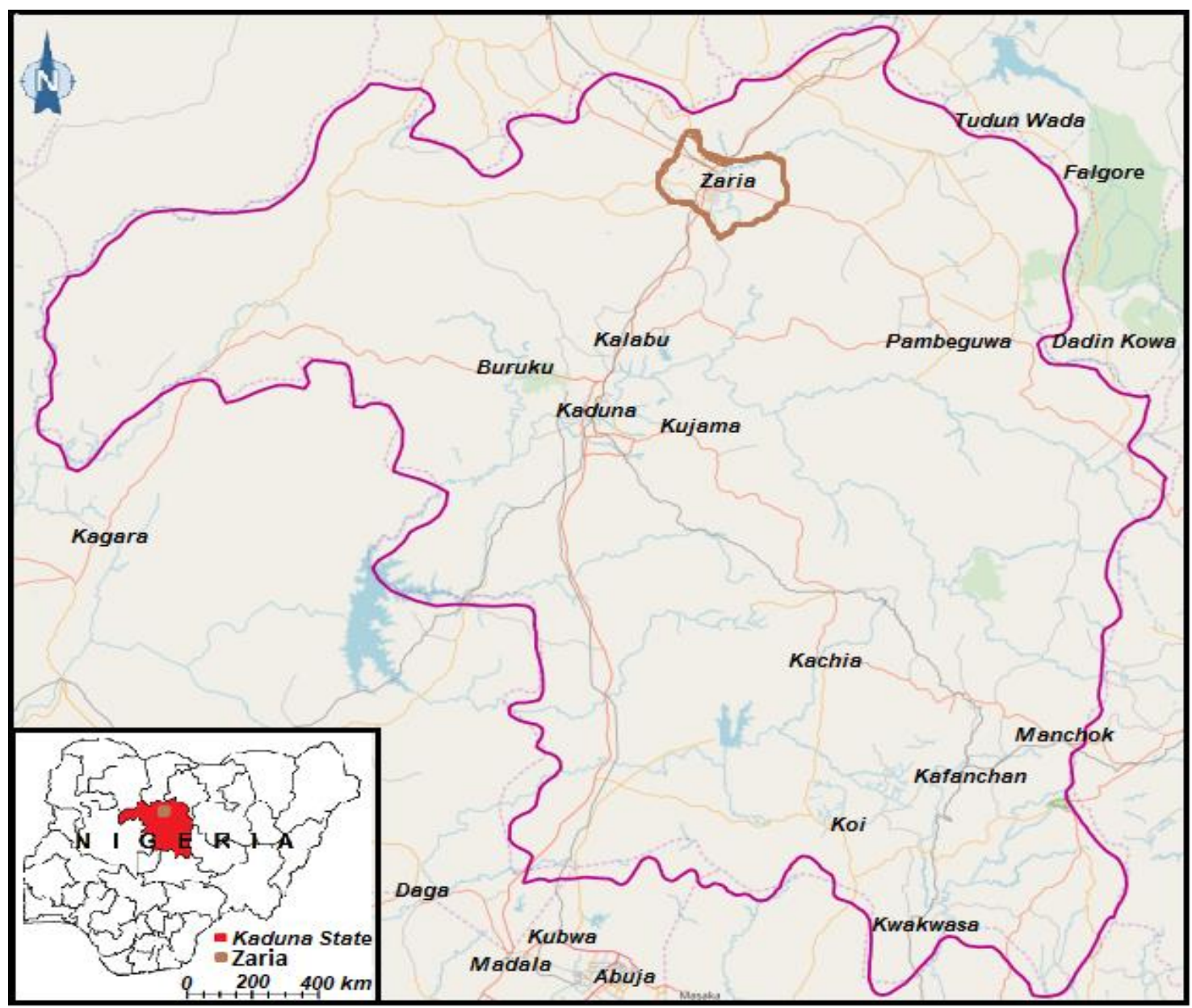

Figure I: Kaduna State of Nigeria

\section{Literature review and theoretical framework}

The Almajirai system: informal education, benign workforce or security concern in Nigeria?

The subject of Almajirai and what it repesented in earlier times and present day sociocultural system of northern Nigerian often elicits varying reactions from citizens. It is an ancient tradition for poor families in rural areas in northern Nigeria and in neighboring countries to send their children to Islamic boarding schools in the north. Once there, the children often receive little education and have no financial support from their parents. Prior to the emergence and dominance of western education, Almajirai were held in high esteem and welcomed, fed and accommodated by host communities while Mallams (teachers) were sponsored by emirs. The pupils worked the farms given to their Mallams by traditional rulers and gathered firewood which they used to read at night. They also assisted the families of their Mallams by performing domestic chores in return for food, and no pupil was taxed, as the teacher gets his reward from Allah. Currently, most Almajirai lack the attributes of past scholars, such as endurance, morals, and discipline, and their intellectual capacity is low. As a result, they are highly vulnerable to abuse and criminal activities (Rigasa et al. 20I5).

It is important to note that the Almajirai used to be the largest segment of the community workforce and made significant contributions to the socioeconomic wellbeing of Muslim communities in northern Nigeria before the advent of white collar jobs. The system was said to have produced judges, clerks and experienced administrators in the precolonial North and Almajirai were reportedly the first to be recruited by the colonial government (Abdullahi 2017: 157; Aghedo and Eke 2013). However, with advent of western education, the Almajirai were gradually replaced as a potent community workforce and abandoned. Consequently, they became victims of negative government policies, public persecution and persistent ethno-religious violence while also being vulnerable to all kinds of abuse (Abdullahi 2017; Rigasa et al. 2015). Today, the Almajirai may be regarded as part of the reserve army of labour, a concept in Marx's Critique of Political Economy. Although they are children, they still belong to the socalled relative surplus population (Nwosu et al 2016) and remain a significant part of the waste management process in northern Nigeria. They are characterized by dangerous working conditions due 
to increased demand for waste management services. The problem posed by waste constantly requires the Almajirai as their labour commodity comes in handy and cheap. Hence, instinct and desperate means for survival has been the driving force for their engagement in SWM.

With the focus of the SDGs on inclusive development of vulnerable groups such as children, there is need to critically engage in the debate to situate the Almajirai SWM system within the social economy of Nigerian urban space. Perhaps, this could yield insights into their motivations and modus operandi and possible areas of intervention in line with the objectives of the SDGs. A brief discourse on the origins of the Almajirai phenomenon will be apt in situating their activities in development context. The word "Almajiri" emanated from Arabic word 'Almuhajir' meaning immigrants. The name was given to Qur'anic pupils in most of the present day Northern Nigeria, because they left their home towns usually to other places or to a particular teacher to obtain sound Qur'anic education. Almajiri is a general name given to both student and destitute but with different meaning to each. Whereas Almajiri (student) is meant generally for Qur'anic student, Almajiri (destitute) is simply a beggar (whether child or adult). Almajiri (student) too begs for alms and food, but only after school break or on school-free days unlike Almajiri (beggar) who only stops begging when he falls asleep. Adama (2014: 159) notes that 'while the debate continues, what is not in doubt is that there are millions of Almajirai in the north and they remain largely excluded from the larger society' and have remained highly vulnerable.

Instructively, some of the more resourceful Almajirai engage in waste picking, recycling and disposal as an alternative means of livelihood to begging (Adama 20l0, 20I2). These waste pickers go from house to house in the early hours of the day to collect waste and then transport them in sacks, cart or wheel barrow to dumpsites. In the northern part of Nigeria, waste pickers who are often referred to as 'Masu Kwashe Shara' and they are arguably important stakeholders in the municipal solid waste management process (Rigasa et al 20I5). In the city of Zaria, Almajirai perform a crucial role by filling the gap left by formal waste management authorities in low income settlements. The younger ones aged between 5-17 actively collect and dispose household waste, while the older ones (Mai Kwalabe) between ages $18-30$ pick and sort recyclable materials such as glass, plastics and metals from the waste dumps. By recovering an appreciable volume of waste material from the waste stream, they contribute to environmental sustainability, albeit by default, since they engage in the activity primarily to earn a living
(Adama, 20I2). However, there is often a downside to their SWM activities as some Almajirai dump waste indiscriminately at the roadside, water bodies or drainage channels. This tends to run counter to the potential environmental sustainability outcomes of Almajirai involvement in SWM.

Perhaps, not well known and not clearly understood is the potential of actors in the Almajirai SWM system to contribute to either alleviating or exacerbating security concerns in the face of growing threat of terrorism in Nigeria (Aghedo and Eke 20|3). Accordingly, Adama (20/4: 159) has argued that 'a stipulation that the Almajirai are expected to contribute to the maintenance of the Mallam and to fulfil their obligations to Mallam could make them vulnerable to inducements from terror groups such as Boko Haram'. The children are disproportionately exposed to various hazards which increase their vulnerability and inhibit their social development and quality of life expectations (Parizeau 2006; Nzeadibe et al. 20|2).

The Almajirai phenomenon also raises issues of national security. For example, there are reports of Almajirai being used as foot soldiers in violent clashes by extremist groups in the north (Adama 2011; Aghedo and Eke 2013). This remark by Aghedo and Eke (20।3: 99) is instructive:

'Almajirai do not only constitute the largest number of out-of-school children in the country and a tremedous (sic) challenge to the realization of both national and international conventions and protocols related to children, including education for all objectives and the millennium development goals, but also pose a direct threat to national security'.

This view is further supported by Oladosu (2012: 3266) who noted that many Almajirai are:

'exploited and used by the politicians as thugs and hoodlums to foment trouble, cause a riot, disrupt peace and achieve selfish political interest. In fact, it has been alleged that most of the terrorist attacks involving suicide bombings, setting places of worship ablaze, killing innocent souls and destroying property were masterminded by jobless pupils of the Al-majiri schools'.

According to a Mallam interviewed in Zaria, there are three categories of children on the streets namely 'the Almajirai under the tutelage of a Mallam (teacher), dropouts from the Almajiri schools and homeless kids probably orphans or those that ran away from their homes'. The second and third types are those that are the most discussed and branded with negative narratives in the popular discussions and in the media.

While the Almajirai are largely excluded from the rest of the society, this study notes that with the prevailing insecurity in Nigeria, idle, unhappy and 
disgruntled people such as the Almajirai are susceptible to becoming a ready workforce and willing recruits for terror groups (Rigasa et al 2015). This view resonates with Jibrin Ibrahim of the Centre for Democracy and Development, a think tank who stated that:

"Eleven million children between 5 and 15 years of age in Northern Nigeria are not living with their families. They have been sent away to learn the Koran. It is a huge pool that extremists can draw from to recruit members" (Nordic Africa Institute 2015).

In the light of the apparent suspicion of posing security threats in their unbridled state, the present research contends that investing in improving the socio-material conditions of the Almajirai could be an approach to alleviating current security concerns in northern Nigeria. In other words, improving the socio-economic well-being of Almajirai through empowerment and giving them a sense of inclusion through policy could enable them to serve as valuable resources to the society (Mbah and Nzeadibe 2017).
As noted earlier, some of these abandoned and excluded children engage in informal waste management as an alternative means of livelihood to begging (Adama 20l0, 20I2). According to Ahmed, an Almajiri who works as a waste picker after their Islamic education often encounters security challenges in the course of carrying out collection of waste, transportation and disposal. They could be easily knocked down by reckless motorists; they are also prone to kidnap by ritualists; they may also be exposed to accidents and possible death at the dumpsite because of the flammable and explosives nature of waste materials. They are sometimes perceived as thieves and beaten up by households. Hence, in areas where thefts have occurred, their security is often not guaranteed irrespective of who the culprit is ${ }^{\text {vi }}$. Table I shows public perception of role of Almajirai involvement in solid waste management in Zaria while Table 2 presents public perception of security implications of Almajirai in SWM.

Table I: Public perception of role of Almajirai involvement in SWM $(\mathrm{N}=350)$

\begin{tabular}{llcc}
\hline S/N & Nature of perception & Frequency & Percentage \\
\hline I & Bridging the gap in waste collection & 56 & 16 \\
2 & Maintaining a clean environment & 140 & 40 \\
3 & Contributing to a healthy environment & 105 & 30 \\
4 & Prevention of pollution & 14 & 4 \\
5 & Prevention of rodents, pests and diseases & 35 & 10 \\
& Total & 350 & 100
\end{tabular}

Source: Fieldwork (2016)

Regarding public perception of security implications of Almajirai in SWM, some respondents (44\%) indicated that the Almajirai are used as agents of destruction especially during religious crises where they act as spies. They can also be easily brainwashed by extremist groups to kill or engage in suicide bombings in order to earn a place in paradise. In this connection, Onuoha (2014: 3) argues that 'Boko Haram draws its members mainly from disaffected youth, unemployed high school and university graduates, and destitute children'.

Table 2: Public perception of security implications of Almajirai in SWM $(\mathrm{N}=350)$.

$\mathrm{S} / \mathrm{N}$ Security challenges $\quad$ Frequency $\quad$ Percentage (\%)




\begin{tabular}{llcc}
\hline 2 & Being beaten on allegations of stealing & 56 & 16 \\
3 & Involvement in acts of terror & 154 & 44 \\
4 & Kidnapping by ritualists & 70 & 20 \\
5 & Others & 35 & 10 \\
& Total & 350 & 100 \\
\hline
\end{tabular}

Source: Fieldwork (2016)

In spite of these perceptions, Ahmed et al. (20|7) draw attention to the utilitarian value of the occupation of child waste picking to northern Nigerian society such as the discipline, social harmony, entrepreneurship and resourcefulness the occupation has helped to create. These authors suggest that by such productive engagement, there have been fewer incentives available for children to engage in crime, drugs and social vices. We argue that contribution to alleviating insecurity by the ISWM sector may be realized if the sector is positively engaged with and appreciated by the public through inclusive MSWM policy which will cater for the wellbeing of informal waste workers. In sum, Almajirai can potentially be a resource to cities in northern Nigeria, as well as a 'double edged sword' which, if not properly managed, can pose some risks to the society (Nwosu et al 2016).

It is important to note that the Almajiri educational system was vigorously supported by the administration of President Goodluck Jonathan through the establishment of schools (Omoju and Abraham 2014).Unfortunately, politics since his exit from power has taken a toll on the once thriving Almajirai education system of northern Nigeria and it is currently in danger of collapse (Mac-Leva et al 2017; This Day Newspaper 2017). On the other hand, Almajirai in SWM can also be a benign workforce that contributes to the sustainability agenda while it may also be a potential security threat if not carefully handled. In sum, this research hypothesizes that not giving primacy to the sociomaterial conditions affecting the quality of life of actors in the Almajirai waste economy in urban policy formulation and implementation may be inimical to society. Figure 2 shows an Almajiri cart pusher in Zaria, a veritable workforce in SWM in northern Nigeria. The next section theorizes SEJ in SWM in sub-Saharan Africa in order to ground this research in international development and human geography thinking.

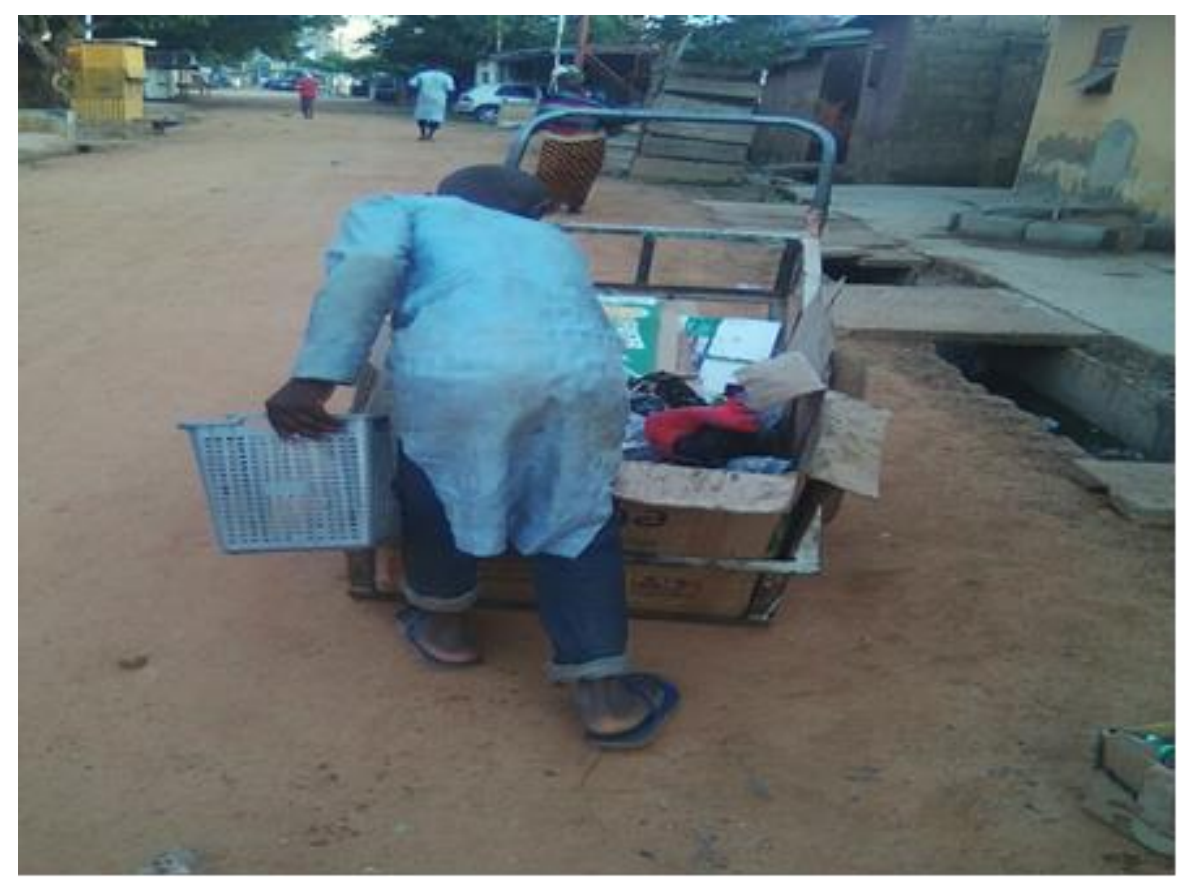

Figure 2: An Almajiri cart pusher in Zaria 
Socio-environmental justice in solid waste management in sub-Saharan Africa

Although it has recently been argued that 'environmental justice in sub-Saharan Africa is highly mediated by political, historical, social, economic and ecological factors' (Mupara et al. 20I7: 3), research in social and environmental justice (SEJ) in the SWM sector in African cities has been neglected for too long in African urban research. With notable exceptions of Kenya and South Africa in relation to SWM and environmental impact of development projects (Njeru 2006; McDonald 2004; Scott and Oelofse 2005; Patel 2009, 20I4) and more recently in Democratic Republic of Congo (Kubanza and Simatele 2015; Simatele and Etambakonga 2015; Kubanza et al. 2017), SEJ research in many subSaharan African cities has been conspicuously absent (Myers 2016). Indeed, earlier studies relating to SWM in sub-Saharan Africa have variously applied the urban political ecology framework to examine environmental justice questions in general (Njeru 2006; Myers 2008; Patel 20I4), while the sustainable waste management and good governance frameworks have also been utilized to give insight into urban processes at play in and around SWM in African cities (Bjerkli 20 I3a, 20I3b; Myers 20I6).

At a sub-regional scale, recent research utilizing the political economy theory of Relative Surplus Population (RSP) examined the well-being of workers in the informal waste economy in urban West Africa (Nwosu et al 2016). Focusing on Ghana and Nigeria, the study under reference notes the policy neglect of the informal waste management sector which is often rationalised by the tendency of research to equate African informal economies with criminality and cultural dysfunctionality. The study critiqued policies that disregard the welfare of waste workers and argues that a policy strategy that synchronizes the environmental stewardship of the informal waste workers and their well-being, offers a path to achieving sustainable development (Nwosu et al 2016).

While we note the potential of the informal waste economy to contribute to the sustainability agenda, and the blossoming of critical anthropological and urban research dealing with this genre of waste management in Nigeria (see, for example, Adama 2012; Adama and Nzeadibe 2017; Nzeadibe and Anyadike 2010; Nzeadibe 2013; Nzeadibe and Mbah 2015), Nigerian cities have unfortunately benefitted very little from research on SEJ in SWM (Nzeadibe and Adama 2015). A single study (Mbah and Nzeadibe 2017) examined SWM from a policy perspective in Nigeria but merely noted the absence of studies addressing SEJ issues. While the studies above are located mostly in southern Nigeria, similar modicum of attention has, unfortunately eluded cities of northern Nigeria where the Almajirai are an active component of the ISWM system.

More importantly, while Mbah and Nzeadibe (2017) applied the sustainable development goals (SDGs) as the framework of analysis and argued in favour of inclusion of the informal waste economy in post-20I5 SWM policy, very little attention was paid to SEJ with respect to Almajirai. Yet, it has been argued that SEJ 'has become a vital resource in the sustainability debate' (Akpan 2006: 22). Therefore, it cannot be argued too strongly that this view is pivotal to a critical examination of SEJ in the Almajirai SWM system given the obvious vulnerability and deprivation they face and the increasing tendency of these children to constitute societal nuisance if not properly guided, checked or attended to. As Abdullahi (2017: 157) observed, 'the hard times being experienced by families in deprived areas of northern Nigeria are currently driving the evolution of value chains in the informal waste management sector in the urban north. This sector is dominated by deprived Almajirai, orphans, the unemployed and the less privileged. They are characterized by low social status, little or no formal education and a lack of access to the financial opportunities needed for a better quality life'.

In sum, we note that the social environment of Almajirai (including income, education, social security and social relations) is perennially hostile while the physical environment in which they operate (such as shelter, stable ecosystem, peace, sustainable resources) (Nguyen et al 2003) often poses a serious threat to their health and well-being. Similarly, issues of equity (relating to social justice and equality, responsibility for human rights, empowerment of women) (Nguyen et al 2003) constitute important social needs of waste workers that need to be addressed in a sustainable manner. In this context, the findings of Evans and Stoddart (1990) appear pertinent. While the present study is not necessarily about health and health care, we feel strongly that the basic determinants of health model (Evans and Stoddart 1990) contains a number of elements which may be adaptable to SEJ research. Hence, this study argues that SEJ in the Almajirai SWM system needs to be framed in the language of human and environmental rights with a view to creating avenues for better socio-political engagement and interventions previously unimaginable in the informal waste economy (Rosaldo 2016).

Taking cognizance of the utilitarian role of children in informal waste management in northern Nigerian cities (Ahmed et al. 2017; Adama 2014), a case is 
being made for a critical examination of SEJ in the Almajirai SWM system. We therefore ask: what SEJ issues bedevil the Almajirai SWM system of northern Nigeria and how could inclusion of Almajirai contribute to attainment of the SDGs? This is particularly relevant given the call by Myers (201 I: 106) for increasing engagement in 'critical scholarship or policy to questions of urban SEJ in terms of equity and fairness in the distribution of outcomes, opportunities and capabilities of cities'. As noted by Gupta et al. (20/4), the argument for justice and inclusive development is justified for moral, legal, economic, social, security and environmental reasons. We now discuss the living and working conditions of the Almajirai that predispose them to health and well-being challenges while also affecting their ability to perform productive activities and making them susceptible to involvement in social vices.

\section{Discussion}

Socio-environmental aspects of Almajirai solid waste management in Zaria

It would not be superfluous to state that the social and environmental conditions of Almajirai are dismal. Thus, Rigasa et al (20I5: 56I) note that 'Almajiri pupils learn the Qur'an under a teacher (Mallam) without good shelter, food or health care and away from their parents, some of who are hundreds of kilometres away'. Despite the lack of rigid learning schedule and possibly syllabus, the pupils (Almajirai) still engage in karatun alo (learning the recitation of the Qur'an) and karatun ilimi (learning the practices and traditions of the Islamic religion). The long time it takes to learn the Qur'an is due to the unstructured learning process, and poor welfare provisions that force the pupils to go to the streets seeking money, and food, rather than stay in school. The skills possessed and practiced only go to show that the pupils have the readiness and potential to learn some economic skills that can be the basis for livelihood in adulthood. This postulation is buttressed by the aspirations of the pupils with regards to the types of livelihood they wish to pursue in adulthood. Other than these activities indicated earlier, the older pupils are engaged in cap washing, water vendors, laundry services, scrap dealing as major sources of income. The next sub-sections will discuss socioenvironmental aspects of involvement of Almajirai in solid waste management in Zaria based on ethnographic fieldwork.

\section{Housing conditions}

Adequate housing offers comfort, privacy, security and personal dignity to an individual. Availability of housing is often the starting point of informal sector activities while its absence is indicative of disorder in society (Nzeadibe et al 20I2). The traditional Islamic schools like those that were studied use the residence of the Mallam as the school premises with classrooms, and sleeping places. With respect to the living environment, it was observed to have poor facilities and services that are inadequate to support good health, conveniences and privacy. The Almajirai sleep in congested, unventilated and ill-maintained rooms. The Almajirai generally sleep anywhere they find themselves, under the sky and open spaces with little consideration of the dangers the night has to offer. Where the pupils have a room to sleep in, there may be only door frames without a door. The rooms may not have mattresses. Most times, sleeping mats are folded into the roof in the day time and brought down at night and serve as beds. Almajirai endure some of the most perilous conditions in northern Nigerian cities where poor building materials are perpetually at risk from destruction during extreme weather conditions (Mbah and Nzeadibe 2017).

The housing conditions expose the pupils to indignity, danger and dehumanization process from childhood and youth. All these are in addition to the inherent health hazards in the housing circumstances involving overcrowding, which can in turn lead to easy transmission of infectious diseases. As such, the Almajirai remain socio-spatially and environmentally excluded from mainstream of society (Nzeadibe and Anyadike 2012).

\section{Clothing}

The Almajirai are usually not well dressed to be adequately protected from the vagaries of weather and for enhanced personality. In any case, they are never naked. They have few clothes which are often patched, ragged and dirty. Due to the lack of parental care, they always look shabbily dressed except on ceremonial occasions e.g. Eid- el Kabir, Eid-el Fitri. They usually look dirty and wear few clothes because they cannot afford good clothes. Based on field observation, it was found that this is common among the category of Almajirai that engage in begging unlike those who engage in menial jobs especially household collection of waste, transportation and disposal at dumpsites. Wages obtained from the collection of waste from various households are divided into twoone portion to their Mallam and the other portion is used to purchase fairly-used clothes known as "gwonjo". Figure 3 shows a typical Almajiri during waste collection from households in Zaria. 


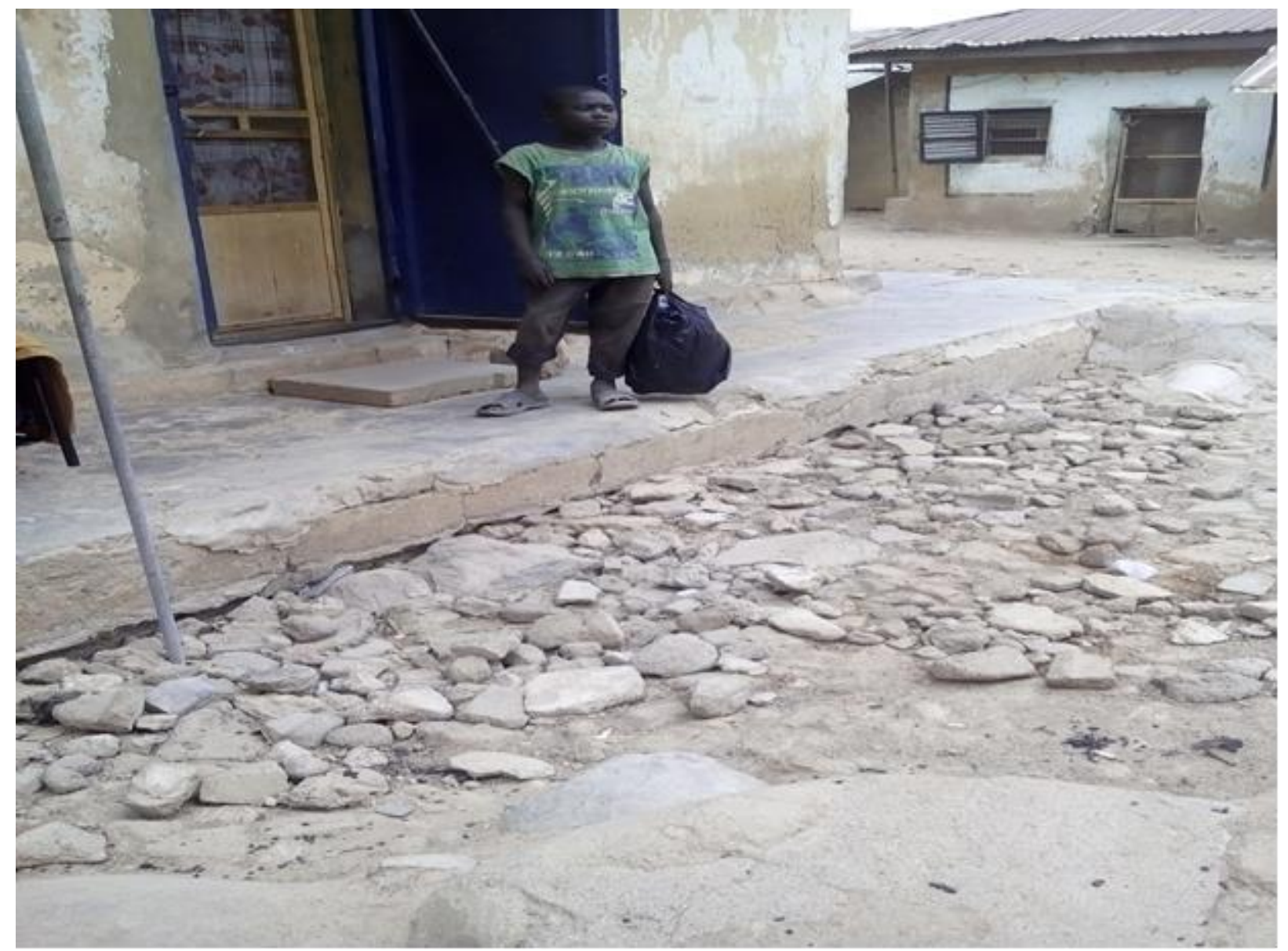

Figure 3: A typical Almajiri collecting waste from households in Zaria

\section{Health conditions of Almajirai}

Improper waste management has continued to take a toll on the health conditions of populations. In Zaria, the Almajirai have continuously been subjected to the hazards and disease (accidents, injuries, infections, etc) conditions arising from this situation. Their frequent exposure to health hazards is compounded because the Almajirai rarely use protective clothing or equipment at work (Figure 3).According to a key informant, 'anyone involved in waste collection, transportation and disposal is exposed to various types of dangers'. This respondent further stated that 'since the Almajirai don't have protective clothing; they are easily exposed to health hazards in the course of solid waste collection and disposal'.

Again, because they do not have access to basic sanitation and potable water supply services, the health, wellbeing and ability of the Almajirai to perform productive activities is often negatively affected. According to a Mallam, 'the school does not provide health care facilities to the Almajirai. Rather, from the money earned, the pupils buy drugs when they are sick'. But if the student is so sick and the Mallam cannot help, the sick pupil is sent back home to his parents, or is left to die even from diseases or sickness that are usually treatable. Ways in which the Mallam can help includes washing the ink used by the sick Almajiri to inscribe their Qur'anic verses on the allo and giving the water to him to drink with prayers being recited. If the symptom persists, the traditional herbal drug known as Magani Gargajiya is administered to him. It is after this, that he is sent home to his parents or left to die if the sickness persists.

The Almajirai suffer from numerous health problems including malnutrition, malaria, gastrointestinal diseases and scabies. Others include tetanus which results from cuts of sharp objects in the course of waste collection, transportation and disposal at the dumpsites. Cold, fever, malaria, typhoid, diarrhea and dysentery also affect them as a result of unwholesome food they collect and consume from the dumpsite as well as from households and exposure to the weather elements. During the focus group discussion, a story was told of an Almajiri who died after consuming food given to him by a woman to dispose of. Unknown to him, the food was poisoned bait earlier used by the woman to trap and kill rodents in her house.

Some other health hazards experienced in the course of their involvement in SWM include joint http://aps.journals.ac.za 
injuries from lifting heavy waste containers and driving loading equipment; respiratory illness from ingesting particulates, bio-aerosols and volatile organics during solid waste collections and from working in smoky and dusty conditions at open dumps causing pneumoconiosis (infection from direct contact with dust) and contaminated materials; dog and rodent bites; disease infections, especially from picking medical waste; injuries at dumpsites due to surface subsidence, underground fires and slides; headaches and nausea from anoxic conditions where disposal sites have high methane, carbon dioxide and carbon monoxide concentrations, and lung poisoning from burning materials with lead-containing batteries, paints and solders which are very dangerous to human health and lives of the individual in the environment.

\section{Water supply and sanitation}

In the Islamic education system of northern Nigeria, water is needed for drinking and personal hygiene as well as ritual activities of mallam and pupils. Availability and access to safe water is a major control for the spread of water borne diseases. However, Almajirai do not have access to potable water supply. They often use unwholesome sources of water including packaged water locally referred to as "pure water"- for their daily needs. Water purchased or collected from various sources are stored in various containers such as buckets, pots and bottles. Thus, it can be said that water supply is problematic to the pupils, and the search for water has the capacity to put extra pressure on the health and the economy of the pupils. The search for water may also interfere with their activities (e.g. waste collection) as well as their studies. Additionally, Almajirai lack sanitation facilities required for the privacy, health and dignity of a human being. The Almajirai mostly defecate in the open field and in open drainage within or on the outskirts of the town. Thus, the pupils live in less than dignifying and more dehumanizing situations.

\section{Economic well-being}

A reason why the Almajirai engage in menial jobs such as collection of wastes from households is to enable them to pay their Mallam. The pupils could be caned if they go back to school without cash for the Mallam. When the activity of waste collection is carried out by the Almajirai, an amount ranging from 10 to 150 is given to them in exchange for their services. The amount payable is dependent on the quantity of the waste collected from the households. In some cases, food is given to them in addition to the money paid them. Some of the Almajirai indicated during interviews that they could make an average of I I 50 daily depending on the number of households, shops and streets covered. From this money generated, they fed, clothed, saved up for the future and also gave to their Mallam in appreciation to the services rendered to them.

Linking socio-material well-beign and Almajirai in the context of the SDGS

It has been argued that inclusion is central to the SDGs (Mbah and Nzeadibe 2017; Pouw and Gupta 2017). The SDGs targets specifically relating to children and the need to protect and improve their well-being conditions (United Nations Department of Economic and Social Affairs 2015) are as follows:

- I.2: By 2030, reduce at least by half the proportion of men, women and children of all ages living in poverty in all its dimensions according to national definitions;

- 2.2: By 2030, end all forms of malnutrition, including achieving, by 2025, the internationally agreed targets on stunting and wasting in children under 5 years of age, and address the nutritional needs of adolescent girls, pregnant and lactating women and older persons;

- 3.2: By 2030, end preventable deaths of newborns and children under 5 years of age, with all countries aiming to reduce neonatal mortality to at least as low as 12 per 1,000 live births and under-5 mortality to at least as low as 25 per I,000 live births;

- 4.5: By 2030, eliminate gender disparities in education and ensure equal access to all levels of education and vocational training for the vulnerable, including persons with disabilities, indigenous peoples and children in vulnerable situations;

- 11.2: By 2030, provide access to safe, affordable, accessible and sustainable transport systems for all, improving road safety, notably by expanding public transport, with special attention to the needs of those in vulnerable situations, women, children, persons with disabilities and older persons;

- II.7: By 2030, provide universal access to safe, inclusive and accessible, green and public spaces, in particular for women and children, older persons and persons with disabilities; and

- 16.2: End abuse, exploitation, trafficking and all forms of violence against and torture of children.

It is unarguable that non consideration of the socio-material conditions affecting the quality of life of children especially those in the informal waste economy such as Almajirai in urban policy formulation and implementation can indeed be inimical to society. This study observes that neglect of the status and needs of informal waste workers can be a source of pain to cities while on the contrary, engendering feelings of self-worth and worthwhileness of the workers can have societal benefits. In this regard, the views of Nunn and 
Gutberlet (2013: 454) regarding this observation are quite revealing. These authors argue that:

'...self-awareness of their value in society is an important precondition to shifting social perceptions and raising awareness of their social importance. This promotion of a shared identity is a political act that emotionally resonates among those working with recyclable materials throughout Brazil. Due to the collective support and iterative self-affirmation of the significance of their work ...feelings of honour, dignity and pride in their work justify their dedication to their activity. This positive production of emotions found in the sector enables recyclers to carry out their work with their heads held high'.

The above scenario was alluded to by Adegboyega Adepitan founder and Executive Director of Waste Collection Workers Welfare Initiative a non-profit organization for the welfare and material well-being of waste pickers in Nigeria, who argues that provision of employment opportunities and social inclusion to people who would have been threats to the security of the society is profiting to the society. Accordingly, the society will benefit by empowering thousands of people engaged in menial jobs, such as informal waste workers (Nunn and Gutberlet 2013), who for one reason or the other, may easily be displaced from their sources of livelihood and thrown into the labour market thereby rendering them vulnerable to the manipulations of mischief makers. Hence, improving their socio-economic well-being through empowerment and giving them a sense of inclusion could prevent such people from constituting themselves into a security risk to the nation. This view seems to resonate in the light of the tendency of governments and development agencies to overlook or ignore the status and needs of informal waste workers in political economic, urban and environmental planning policy in Africa (Watson 20I I; Nzeadibe et al. 20I2). In this sense, this study argues that the society cannot afford to ignore the socio-material and emotional needs of Almajirai. Thus, their socio-environmental well-being could dovetail with public health, security and functioning of northern Nigerian cities.

Conclusion: scaling up engagement with almajirai in solid waste management in Northern Nigeria

From the discourse so far, it is apparent that the need for positive engagement of Almajirai in SWM in northern Nigerian cities cannot be overemphasized. This research has identified the triple challenges of unemployment, insecurity and environmental problems as areas amenable to being addressed if inclusive policies are adopted towards the Almajirai waste economy. This suggestion apparently received tacit endorsement during the 2014 Nigerian National Conference in which Bolaji Akinyemi during adoption of recommendations of committee reports remarked that 'any scheme that will mop up unemployment should be encouraged'.

Recently, efforts have been initiated by the Kaduna State government to partner with Almajirai in the 'waste to cash' initiative where residents would get cash for their refuse. This initiative was carried out in collaboration with a corporate body, Zoom Lion Global Alliance. According to officials of the company, 'As a way of further encouraging the Almajirai in the waste collection process for cash, any one with the most collected trash aside the money to be paid such person will win a motorcycle while whoever comes second and third will win additional cash prize' (Benjamin 20I6; Alabi 20I6).

Again, the case of the NGO Development Association for Renewable Energies (DARE) recruiting and utilizing the skills of street children in filling sand in bottles for the innovative green construction of houses in SabonYelwa in northern Nigeria is an important example of positive engagement of the energies of young people such as the Almajirai in SWM which has both environmental and social values (Adama 20I2c:16). This study suggests that the society may be worse off if the waste workers do not benefit from emotional satisfaction of inclusive urban policy. It is further argued that given the prevailing security, employment and environmental challenges, any responsible government would do well to consider the well-being of waste workers. Policy-level recognition of the informal waste economy as stakeholders in the SWM process and contributors to the urban economy and poverty reduction is here canvassed as imperative to achieving these objectives.

This study recommends that every Almajiri below the age of 18 years should not be allowed to be involved in SWM but be given the opportunity of enjoying his childhood especially by going to school. On the other hand, other Almajirai from 18 years and above could be integrated into the SWM policy of the state and thus earn a decent living which will therefore lead to meeting ones ends as well as reduce the rate of crime in Zaria and the northern part of Nigeria as a whole.

Even though most Almajirai fall below 18 years of age, they play a very important role in SWM in Zaria. As a result of their tenderness, they are often exposed to both health and security challenges. Based on the findings of this research, government should provide basic amenities for them. They should also be entitled to basic education first and not to be subjected to hustling at a very tender age. Revival and 
adequate funding of the Almajiri schools established by a previous government in Nigeria should be given priority by state governments in northern Nigeria. Such inclusive development should be insulated from political manipulations as it will be in the long-term interest of the region to do so. The Child Rights Act needs to be domesticated and its provisions implemented in all states of northern Nigeria. By so doing, the state governments will be working towards 'leaving no one behind'.

Furthermore, irrespective of the role they play, the younger ones should not be integrated into the waste management policy but be allowed to go to school to acquire either western or Islamic education whereas the older ones who are considered adults according to the Nigerian constitution should be integrated into the solid waste management policy. This could be an approach towards addressing the high incidence of unemployment and crime. Development NGOs could initiate intervention measures to alleviate the health and social needs of the waste workers and give them voice in urban governance and public policy in the post-20I5 era.

Author/s guarantee form: All named authors have contributed sufficiently to the work submitted and the content of the manuscript has never been previously published.

\section{Acknowledgement}

The authors acknowledge the participation and input of different stakeholders to this research.

Grateful thanks also go to Chinedu Ogbodo of the GIS Laboratory, Department of Geography, University of Nigeria, Nsukka for cartographic assistance.

\section{References}

Abdullahi, Y.R. 2017. Survival in the margins: Almajiriand waste management in north $\neg$ ernNigerian urban centres. In Adama, $\mathrm{O}$. and Nzeadibe, T.C.(eds), Dealing with waste: resource recovery and entrepreneurship in informal sector solid waste management in African cities (pp.15I-166). Trenton, NJ: Africa World Press.

Adama, O. 2012a. Urban livelihoods and social networks: Emerging relations in informal recycling in Kaduna, Nigeria. Urban Forum 23(4): 449-466. DOI: $10.1007 / \mathrm{s} / 2$ |32-0I2-9159-8.

Adama, O. 20I2b.Living on the Fringes: Almajirai and Informal Solid Waste Management in Kaduna, Nigeria. Paper presented at the 2012 Nordic Africa Days Conference, Uppsala, October 18th 2012.
http://conference.hi.is/nad20I2/files/20I2/0I/Pane I-3I.pdf

Adama, $0.2012 c$.Informal Recycling. The NAI Annual Report, 2012. p. 16. Uppsala: The Nordic Africa Institute.

Adama O.20II.Almajiri caught in Cross Fire: Capacity of informal workers rarely recognized. The NAI Annual Report, 20I I, p.34-36.

Adama, O. 2014. Marginalisation and integration within the informal urban economy: the case of child waste pickers in Kaduna, Nigeria. International Development Planning Review, 36 (2), I55-I80, doi: I0.3828/idpr.20 |4. I I

Adama, O. and Nzeadibe, T.C.(eds).2017. Dealing with waste: resource recovery and entrepreneurship in informal sector solid waste management in African cities. Trenton, NJ: Africa World Press.

Adeyemi A.S., Olorunfemi J.F., and Adewoye T.O.200I. Waste Scavenging in Third World cities: A case study in llorin, Nigeria .The Environmentalist, 2I(2), 93-96.

Aghedo, I and Eke, S.J.2013. From Alms to Arms: The Almajiri Phenomenon and Internal

Security in Northern Nigeria. The Korean Journal of Policy Studies, 28(3), 97-I23.

Agunwamba J .C. 2003. Analysis of Scavengers' Activities and Recycling in some cities of Nigeria. Environmental Management, 32 (I), I I6-I 27.

Ahmed, A., Adama, O. and Aliyu, I.I. 2017.Prospects and retrospect: insights from children's participation in informal sector solid waste management in Kaduna, Nigeria. In Adama, $\mathrm{O}$ and Nzeadibe, T.C.(eds), Dealing with waste: resource recovery and entrepreneurship in informal sector solid waste management in African cities (pp.|37-150). Trenton, NJ: Africa World Press.

Akpan, W.2006.Environmental Racism: Oil and the 'Glocalisation' of Environmental Justice

Discourse in Nigeria. African Sociological Review, $10(2), 18-42$.

Alabi, C.T.2016. Kaduna engages almajiri pupils for waste-to-cash project. Daily Trust

Newspapers, September 15 2016. Accessed on $\begin{array}{llll}\text { October } & 8 & 2016 & \text { from }\end{array}$ http://www.dailytrust.com.ng/news/general/kadun a-engages-almajiri-pupils-for-waste-to-cashproject/ /62576.html

Aluaigba,M.T.2009. Circumventing or Superimposing Poverty on the African Child? The Almajiri syndrome in Northern Nigeria. Childhood in Africa I(I), 19-24

Awofeso, N., Ritchie, J., \&Degeling, P. 2003. The Almajiri heritage and the threat of non-state terrorism in northern Nigeria: Lessons from 
Central Asia and Pakistan. Studies in Conflict and Terrorism, 26(4), 3II-325. DOI: 10.1080/I0576/00390208260

Benjamin, I.2016. Environmental Expert Engage Almajiri in 'Cash For Trash' Project in Kaduna. Leadership Newspapers, September 142016. Accessed on October 82016 from HTTP://LEADERSHIP.NG/NEWS/550577/ENVIR ONMENTAL-EXPERT-ENGAGE-ALMAJIRI-IN$\%$ E2\%80\%8ECASH-FOR-TRASH-PROJECT-INKADUNA

Buckingham, S., Reeves D., and Batchelor, A. 2005. Wasting women: The environmental justice of including women in municipal waste management. Local Environment: The International Journal of Justice and Sustainability I0(4), 427-444

Citizen's Platform for SDGs, Bangladesh. 2017. SDGs are against environmental discrimination and for environmental justice. Accessed on 23rd September 2017 from http://bdplatform4sdgs.net/2017/05/28/sdgsenvironmental-discrimination-environmentaljustice/

Coles, C.1991. Hausa women's work in a declining economy: Kaduna, Nigeria, 1980-1985. .In: Coles, C. \& Mack, B. (Eds.), Hausa Women in the Twentieth Century. Madison: University of Wisconsin Press (pp.3-26).

Environmental Justice Network Forum .1997. Environmental Justice Networker, Autumn, cited in McDonald 2004, p.4.

Evans, R.G. and Stoddart, G.L. 1990 .Producing Health, Consuming Health Care.Social Science and Medicine 3 I ( 2), I 347- I 363.

Gupta, J.,Baud, I., Bekkers, R., Bernstein, S., Boas,I., Cornelissen, V., Iguchi, M., Kanie, N.,

Kim, R.E., Lima, M.B., Obani, P., Schoof, P., Stevens,C., and van Zoomeren, D.2014. Sustainable Development Goals and Inclusive Development. POST20I5/UNU-IAS Policy Brief \#5. Tokyo: United Nations University Institute for the Advanced Study of Sustainability. Retrieved on $9: 11: 15$ from http://collections.unu.edu/eserv/UNU:2567/Post2 0I5_UNUIAS_PolicyBrief5.pdf

Haregu, T.N., Ziraba, A.K and Mberu, B. 2016. Integration of solid waste management policies in Kenya: Analysis of coherence, gaps and overlaps. African Population Studies 30(2) Supplement, 2876-2885.

Hunt, C.I996.Child waste pickers in India: the occupation and its health risks. Environment and Urbanization, 8(2), I I I-I I8.
International Labour Organisation. 2004. Addressing the Exploitation of Children in Scavenging (Waste Picking): A Thematic Evaluation on Action on Child Labour Geneva: International Labour Organisation.

Kubanza, N.S and Simatele, D. 2015. Social and environmental injustices in solid waste management in sub-Saharan Africa: a study of Kinshasa, the Democratic Republic of Congo. Local Environment 2I(7), 866-882.

Kubanza, N. S., Das, D. K., \&Simatele, D. 2017. Some happy, others sad: exploring environmental justice in solid waste management in Kinshasa, the Democratic Republic of Congo. Local Environment, 22(5), 595-620. http://dx.doi.org//0.1080//3549839.2016.1242/2 0

Landrigan , P.J., Rauh , V.A., and Galvez , M.P.20I0.Environmental Justice and the Health of Children. Mount Sinai Journal of Medicine: A Journal of Translational and Personalized Medicine, 77(2), I78-187

Mac-Leva, F; Umar, S., Adebayo, I. and Auwal, A. 2017. NI5 billion Almajiri Schools in ruins.

Daily Trust. Monday, November 27, 2017. Accessed https://www.dailytrust.com.ng/nl5billion-almajiri-schools-in-ruins.html

Mbah, P.O and Nzeadibe, T.C. 20I7.Inclusive municipal solid waste management policy in

Nigeria: engaging the informal economy in post2015 development agenda, Local Environment, 22(2),

203-224,

DOI: | 0.1080/| 3549839.20|6.| | 88062

McDonald, D. A. 2004. Environmental Justice in South Africa. Juta and Company Ltd.

Mupara, S.W., Nkuba, M.R., and Gwebu, T.D.20I7.Intra-urban patterns of domestic solid waste recycling in sub-Saharan Africa: towards an exploratory search for insights in Gaborone, Botswana. Geojournal. DOI 10.1007/s 10708-01798II-x

Myers, G. 2008. Sustainable development and environmental justice in African cities. Geography Compass, 2/3, 695-708.

Myers, G. 20II. African cities: Alternative visions of urban theory and practice. London:

Zed Books.

Myers, G. 2016.Urban Environments in Africa: A Critical Analysis of Environmental Politics.

Bristol: Policy Press.

Nguyen, H., C. Chalin, T. Lam, and V. Maclaren. 2003. Health \& Social Needs of Waste Pickers in Vietnam. Research paper, CIDA WASTE-ECON programme South East Asia. Retrieved from 
http://www.utoronto.ca/wasteecon/HuyenNguyen.pdf on 25:02:20I I.

Nordic Africa Institute. 2015.Children away from home are easily recruited by terrorists.

Uppsala: Nordic Africa Institute. Retrieved on 07:08:15

from

http://www.nai.uu.se/news/articles/2015/07/I4/II 2536/index.xml

Nwosu, B.U., Nzeadibe, T.C., and Mbah, P.O. 2016. Waste and wellbeing: a political economy of informal waste management and public policy in urban West Africa. Review of African Political Economy, 43(149), 478-488, DOI: I0.1080/03056244.20|5.10849|4

Nzeadibe, T.C. 2009.Solid waste reforms and informal recycling in Enugu urban area, Nigeria. Habitat International, 33 (I), 93-99. DOI:10.1016/j.habitatint.2008.05.006.

Nzeadibe, T.C. and Ajaero, C.K. 20I I. Development impact of advocacy initiatives in solid waste management in Nigeria. Environment, Development and Sustainability, I3(I)I63-I77. DOI: 10.1007/s I 0668-010-9254-8.

Nzeadibe, T.C., Anyadike, R.N.C. \&. Njoku-Tony, R.F. 2012. A mixed methods approach to vulnerability and quality of life assessment of waste picking in urban Nigeria. Applied Research in Quality of Life. 7(4), 35I-370. DOI: |0. |007/s | |482-0| 2-9|7|-0.

Nzeadibe, T.C. and Adama, O.20I5. Ingrained inequalities? Deconstructing gendered

spaces in the informal waste economy of Nigerian cities .Urban Forum 26(2), I|3-|30. DOI: I0. I007/s | 2|32-0|4-9246-0.

Nzeadibe, T.C and H.C. Iwuoha. 2008. Informal waste recycling in Lagos, Nigeria.

Communications in Waste \& Resource Management 9(I) 24-30.

Nzeadibe, T.C and Mbah, P.O.20I5.Beyond urban vulnerability: Interrogating the social

sustainability of a livelihood in the informal economy of Nigerian cities. Review of African Political Economy, 42(I44), 279-298. DOI: 10.1080/03056244.2014.997692

Oladosu, A. G. A. S. 2012. Arabic and Islamic education in Nigeria: The case of Al-Majiri

schools. International Scholarly and Scientific Research \& Innovation 6(I I), 3265-3269

Omoju, O. and Abraham, T.W. 20I4.Youth bulge and demographic dividend in Nigeria. African Population Studies 27(2):352 - 360. DOI: 10.1 I 564/27-2-480

Onuoha, F.C. 2014. Why do youth join Boko Haram? United States Institute of Peace Special Report No. 348, June 20I4. Retrieved on 09/07// 4 from
http://www.usip.org/sites/default/files/SR348-

Why_do_Youth_Join_Boko_Haram.pdf

Onyanta, A.2016. Cities, municipal solid waste management and climate change: Perspectives from the South. Geography Compass 10 (12), 499-5 I3, I0.1 III/gec3.I2299.

Parizeau, K. 2006. Theorizing environmental justice: Environment as a social determinant of health. MCIS Briefings, I0I-I 28.

Patel, Z.2009. Environmental justice in South Africa: tools and trade-offs. Social Dynamics, 35 (I), 94IIO.

Patel, Z. 2014.South Africa's Three Waves of Environmental Policy: (Mis) aligning the Goals of Sustainable Development, Environmental Justice and Climate Change. Geography Compass 8 (3), |69-181. DOI: 10.11।1/gec3.12119

Pouw, N. and Gupta, J.2017. Editorial overview: Sustainability science. Current Opinion in

Environmental Sustainability, 24: iv-vi. http://dx.doi.org//0.1016/j.cosust.2017.03.006

Rigasa, Y.A., Abdulkarim, B.I. and Badamasi, A.G.20I5. Waste management services: $A$

strategy for the integration of "Almajiri" into current waste management action plans of urban centres in Northern Nigeria. Biological and Environmental Sciences Journal for the Tropics I2(I), 558- 565 .

Rosaldo, M. 2016. Revolution in the Garbage

Dump: The Political and Economic

Foundations of the Colombian Recycler Movement, |986-20II. Social Problems, 63 (3): 35I-372.

DOI: http://dx.doi.org/10.1093/socpro/spw0I5

Simatele, D., \& Etambakonga, C. L. 20I5. Scavenging for solid waste in Kinshasa: A

livelihood strategy for the urban poor in the Democratic Republic of Congo. Habitat International, 49, 266-274.

Ukoje, J. E. 20I2. Informal sector solid waste collection and recycling in Zaria, Nigeria.

Journal of Environmental Science and Engineering. $B, I(5 B)$.

Ukoje, J.E.2017.Dynamics of informal sector solid waste recycling in Zaria, Nigeria. In

Adama, O. and Nzeadibe, C.(Eds), Dealing with waste: resource recovery and entrepreneurship in informal sector solid waste management in African cities (pp.|23-136). Trenton, NJ: Africa World Press.

Scott, D. and Oelofse, C. 2005.Social and Environmental Justice in South African Cities: Including 'Invisible Stakeholders' in Environmental Assessment Procedures. Journal of Environmental Planning and Management, 48(3), 445 - 467. 
This Day Newspaper.2017.The abandonment of Almajiri schools. Editorial. Accessed

22:12:17

from: http://www.thisdaylive.com/index.php/20I7//2/22 /the-abandonment-of-almajiri-schools/

UNICEF Nigeria Fact Sheet.20II. Child rights legislation in Nigeria. UNICEF

https://www.unicef.org/nigeria/Child_rights_legisla tion_in_Nigeria.pdf

United Nations Department of Economic and Social Affairs. 2015.Transforming our world: The 2030 Agenda for Sustainable Development. Sustainable Development Knowledge Platform. Accessed on 20th August 2015 from: https://sustainabledevelopment.un.org/content/do cuments/789 I Transforming\%200ur\%20World.p $\mathrm{df}$

Watson, V.20II.Inclusive Urban Planning for the Working Poor: Planning Education Trends and Potential Shifts. Urban Policies Research Report No. II. Women in Informal Employment Globalising and Organising (WIEGO). Retrieved on 26:01:12 from http://www.inclusivecities.org/research/RRI I_Wat son.pdf

Wilson, D.C., Velis, C \&. Cheeseman, C.2006. Role of informal sector recycling in waste management in developing countries. Habitat International, 30 (4), 797-808.

\section{NOTES}

Almajirai (singular Almajiri) are young Muslim pupils of the Islamic education system. Abandoned by their parents and largely ignored by the government and society, they fall within the most disadvantaged and vulnerable urban groups in cities. According to Ahmed et al (20I7: |40-|4|), 'their growing numbers and the way they negotiate their livelihoods has been a source of concern, just as the new forms and styles of urban life and the sociology of the city they have influenced'. See also Awofeso et al. (2003) for a detailed discussion of the Almajiri phenomenon in relation to the potential threat of non-state terrorism and Adama (20I2a) for more insight into involvement of Almajirai in waste collection, resource recovery and recycling in northern Nigeria.

2 It is instructive that the Child Rights Act 2003 has been domesticated in 24 out of 36 states of Nigeria. Eleven of the remaining twelve states that are yet to conform to the Act are from northern Nigeria (UNICEF Nigeria Factsheet 20I I: 2).
3 One of the respondents, Yusuf Abdullahi Rigasa and currently the Director of KEPA, was interviewed at the Policy Round table organized by the Nordic Africa Institute in Abuja in 20I4.

4 Boko Haram is an extremist Islamic group in northern Nigeria which means "Western education is sinful". The group demands strict adoption of Islamic sharia law throughout Nigeria and has been linked to a spate of suicide bombings and terror attacks in Nigeria.

5 Interview with a Mallam in April 2016.

6 Interview with Adamu Ahmed, urban planning specialist and Head, Department of Urban and Regional Planning Ahmadu Bello University (ABU), Zaria

7 Adamu Ahmed raised these issues at the NAI Policy Dialogue in Abuja, August 2014.

8 Some of the Almajirai have been engaged in using sand to make a plastic house (see, for example, Adama 20I2c: 16). This is a conservation project that contributes to greening the environment with commendable social outcomes.

9This study recognizes that there are variants, modifications and criticisms of this model but we argue that the basic model is adequate to explain SEJ in relation to the Almajirai SWM.

10 This view was expressed by Adamu Ahmed, professor, $A B \cup$ Zaria.

II Personal communication with Adegboyega Adepitan on August 21 and November I2 2012.

12 This position receives support from Adama (20/2a) who avers that Almajirai are not always a national security nuisance or helpless victims, but can be a valuable resource to cities in Northern Nigeria as they are actively involved in waste collection in areas where the formal system is non-existent; they also pick waste at the communal dump sites and other public spaces thereby contributing to resource recovery and the green economy.

13 Authors acknowledge Adegboyega Adepitan, Executive Director of Waste Collection Workers Welfare Initiative for suggesting and explicating this view during interviews on August 21 and November 122012. 
African Population Studies Vol 32, No 2, (Supp. 2), Sept. 2018

I4 Bolaji Akinyemi, Deputy Chairman of the National Conference which was convoked by Nigerian President, Goodluck Jonathan to chart a new future, made this remark during a live broadcast course for Nigeria's socio-economic and political 